\title{
Determination of Factors in Cultural Dimensions and SERVQUAL Model Affecting the Corporate Image of Pharmacy Retail Stores*
}

\author{
Worasak KLONGTHONG ${ }^{1}$, Jakkrit THAVORN², \\ Suntaree WATCHARADAMRONGKUN ${ }^{3}$, Chittipa NGAMKROECKJOTI ${ }^{4}$
}

Received: August 01, 2020 Revised: September 06, 2020 Accepted: September 10, 2020

\begin{abstract}
Thailand has a rapidly growing pharmaceutical sector, which is the eighth largest in the Asia-Pacific region and one of the largest and most developed among the Association of Southeast Asian Nations (ASEAN) countries. This study examines how to provide the most appropriate approach to enhance Thailand's pharmaceutical services to dispense medicine to end consumers. The main objective is to determine the most appropriate corporate image for Thai Pharmacy Retail Stores (PRSs) for entering the ASEAN market community. An exploratory mixed-method design characterized by qualitative and quantitative phases of data collection and analysis and the linking of data from these two separate data strands was adopted to conduct an in-depth interview with pharmacists and the owner of pharmacy retail stores as well as 405 respondents who had visited a pharmacy retail store and interacted with pharmacists during the previous year. The multiple linear regression (MLR) was applied to analyze the relative influences of perceived service quality and the cultural dimension on the corporate image. Findings reveal that the perceived service quality and cultural dimension contribute $50 \%$ towards the corporate image, and the perceived service quality had more effect than cultural dimension. This study mainly focuses on PRSs in Thailand, while the findings show other analyses concerning how to successfully create and promote an effective PRS image for ASEAN markets.
\end{abstract}

Keywords: Perceived Service Quality, Cultural Dimensions, Pharmacy Retail Stores, Corporate Image, ASEAN Community

JEL Classification Code: F20, M10, M14

\footnotetext{
*Acknowledgements:

This research was supported by the Graduate School of Business, Assumption University and the Department of Social and Administrative Pharmacy, Faculty of Pharmaceutical Sciences, Chulalongkorn University. This research was supported by the Graduate School of Business, Assumption University and the Department of Social and Administrative Pharmacy, Faculty of Pharmaceutical Sciences, Chulalongkorn University.

${ }^{1}$ First Author and Corresponding Author. Graduate School of Business, Assumption University, Thailand [Postal Address: 92/3 Ramkhamhaeng 24, Hua-Mak, Bangkapi, Bangkok, 10240, Thailand] Email: wklongthong@gmail.com

${ }^{2}$ Graduate School of Business, Assumption University, Thailand. Email: jk.thavorn@gmail.com

${ }^{3}$ Assistant Professor, Department of Social and Administrative Pharmacy, Faculty of Pharmaceutical Sciences, Chulalongkorn University, Thailand. Email: suntaree.w@chula.ac.th

${ }^{4}$ Assistant Professor, Graduate School of Business, Assumption University, Thailand. Email: helen10th@gmail.com

(c) Copyright: The Author(s)

This is an Open Access article distributed under the terms of the Creative Commons Attribution Non-Commercial License (https://creativecommons.org/licenses/by-nc/4.0/) which permits unrestricted non-commercial use, distribution, and reproduction in any medium, provided the original work is properly cited.
}

\section{Introduction}

As part of its Thailand 4.0 initiative, the Thai government aims to establish the country as a leading destination for medical devices and medical and pharmaceutical care (Thailand Board of Investment [BOI], 2018; Ngamsangchaikit, 2016). From 2003-2017, Thailand's healthcare sector grew from USD \$ 8.9 billion to $\$ 17$ billion (Knoema, 2020), and it is expected to increase to $\$ 47.9$ billion by 2026 , reflecting a ten-year compound annual growth rate (CAGR) of 6.6\% (Kingdom of the Netherlands, 2018). As the country's "Medical Hub" policy has gained traction, the value of the Thailand medical device market rose to $70 \%$ from 2009 to reach to 176 billion baht (US $\$ 6$ billion) in 2019 (BOI, 2020), and Thailand is currently the top importer and exporter of such products in the Associations of Southeast Asian Nations (ASEAN). The Thailand Board of Investment (BOI, 2019) estimates that medical tourism in Thailand has been growing at an annual rate of $8.5 \%$ in recent years, and from 2010-2018, the country experienced a $92 \%$ increase in medical tourism from 1.78 million to 3.42 million. 
The World Travel and Tourism Council (WTTC, 2019) ranks Thailand fifth among the world's medical tourism destinations.

Thailand also has a rapidly growing pharmaceutical sector, which is the eighth largest in the Asia-Pacific region and one of the largest and most developed among the ASEAN countries. Thailand's pharmaceutical industry was valued at US\$4.6 billion in 2016 and is projected to grow at a (CAGR) of $6.2 \%$ to reach US $\$ 6.3$ billion by 2021 and US $\$ 8.4$ billion by 2026 (Kingdom of the Netherlands, 2018). Thailand's status as a major importer of pharmaceutical products, including active pharmaceutical ingredients, has given its pharmacists increased access to new medical knowledge and scholar exchange, and the country is poised to expand its pharmaceutical retail stores (PRS) throughout the ASEAN region.

In order to achieve this expansion, the industry must develop a corporate image that extends beyond the domestic market to appeal to consumers in a broader market. Pharmacy practice in the current era is oriented toward patient-oriented activities (Holland \& Nimmo, 1999). When consumers enter a PRS, they will form impressions regarding the service quality of pharmacists, which will be reflected in the organization's corporate image. The challenge of advancing pharmaceutical care is to assist pharmacists to modify their practices and services in a community setting. As a consequence, the pharmacist needs to develop and increase service qualities for consumers.

This article presents the results of the quantitative analysis conducted to extend and test the findings of a previous qualitative study in which specialist pharmacists were interviewed regarding their views of what aspects of their service influence the perceptions of end-consumers who visit Thai Pharmacy Retail Stores (PRS). In that study, it was found that responsiveness and empathy were the major factors influencing perceived service quality according to pharmacists' experiences. In this study, pharmaceutical customers completed surveys regarding their perceptions and experiences with a focus on identifying factors affecting the corporate image of Thai PRS.

\section{Literature Review}

\subsection{Cultural Dimension}

Hofstede (1991) defined culture as collective mental programming that distinguishes the members of one group or category of people from another based on their shared values, beliefs and norms. These mental constructs influence how people socialized within a particular culture perceive events, and they determine what behaviors are considered appropriate or inappropriate in various social situations. In this context, culture refers to relatively enduring personality characteristics that are "common or standardized in a given society".

Hofstede $(1991,2001)$ identified five dimensions of cultural values. First, power distance (PD) refers to the degree to which members of a culture expect and accept that power is unequally distributed. The characteristics of a high-PD are (1) dependent on hierarchy; (2) belief about the inequality of rights between holders of power (power holders) and those who do not power (non-power holders); (3) the leader is directive; (4) managers take control and do delegation; (5) centralized power; and (6) team members must obey the leaders. Second, uncertainty avoidance (UA) refers to the degree to which members of a culture feel threatened by ambiguous or unknown situations, and to what extent they will create a belief in order to avoid the situation. The ambiguity of the future leads to anxiety, and different cultures handle anxiety in many different ways. The central question is: do we have to try to control the future (high UA), or do we tolerate and just let the future happen (low UA)?

Third, collectivism (CO) refers to the degree of interdependence between members of society. A person with a collectivist perspective describes himself/herself by the term "we/us" rather than "me/I". Characteristics of a high CO include: (1) people loyal to the group (in a group); (2) preference for a social framework; (3) an expectation that individuals shall conform to the ideals of the group; and (4) loyalty to family and community. Fourth, masculinity (MA) is concerned with the question of motivations, particularly whether one prioritizes likeability or superiority. Members of high MA cultures are driven by competition, achievement, and success, the latter of which is defined by being the winner or being the best in his/her field, whereas low MA cultures place greater value on caring for other people and their lives. Finally, long-term orientation (LT) denotes the degree to which members of culture show future-oriented pragmatic perspective as opposed to short-term conventional historical perspectives.

In a massive study encompassing seventy-six countries, power distance and uncertainty avoidance have been identified as the two predominant value-oriented dimensions that may be used to describe and explain aspects of behavior in Thai culture (Hofstede Insights, 2020). In this study, these two dimensions are related to the knowledge and service mindedness of pharmacists in providing appropriate suggestions to end-consumers based on their symptoms.

\subsection{Perceived Service Quality}

Perceived service quality is defined as consumers' judgment about a business's overall distinction or dominance (Parasuraman et al., 1988). The SERVQUAL model elaborated by Parasuraman et al. (1988), measures service quality as the discrepancy (gap) between a customer's expectations of a service offering and their perceptions of the service received. Such evaluations depend on a customer's feelings or memory rather than objective attributes (Jiang \& Wang, 2006). Ultimately, customers measure service quality in terms of how much pleasure they have received from the service. If what is perceived exceeds the expectations, then 
customers think quality to be high and if what is perceived below the expectation then customers think quality to below.

Parasuraman et al. (1988) developed ten general dimensions that are evaluated in SERVQUAL, namely tangibles, reliability responsiveness, competence, courtesy, credibility, security, access, communications, and understanding. The authors later revised the model based on the result of an empirical study on five service companies, in which they found correlations among the dimensions, and the finalized instrument was reduced to the five dimensions of reliability, responsiveness assurance, empathy, and tangibles (Parasuraman et al., 1991). Wilson et al. (2017) describe the dimensions as follows: 1) tangibles refer to an organization's physical facilities, equipment, personnel, and communication material; 2) reliability is the ability to dependably and accurately perform the promised service; 3) responsiveness refers to the willingness to help customers and provide prompt service; 4) assurance denotes employees' knowledge, courtesy and ability to convey trust and confidence; and 5) empathy is evaluated based on the provision of caring, individualized attention to the customer.

Several studies that have examined consumers' views of the five service quality dimensions have found that participants ranked responsiveness as being highest in importance, followed by assurance, tangibles, empathy, and reliability, respectively (Abu-Kharmeh, 2012; Pakdil \& Aydln, 2007; Zarei et al., 2012). In the context of the pharmaceutical industry, Afolabi and Erhun (2003) studied patients' perceived service quality based on their visits to PRS and found that the primary areas of concern were reliability and responsiveness, as reflected in participants' reports of experiencing considerable delays obtaining their prescriptions and making payments and their complaints of having only indirect access to dispensing pharmacists. Vilako and Raal's (2007) study of customer expectations in the pharmacy services in Estonia indicated that the highest expectations included help in selecting the right medicine together with the professional consultation. Moreover, Tabash et al. (2019) also studied the effect of service quality dimensions and found that reliability and responsiveness are significant factors in the banking industry. Baber (2019) elaborated the e-service quality dimensions which can enhance the experience in online banking service. Importantly, the service quality was researched to find the relationship with experience value, relationship quality toward behavioral intentions (Tran, 2020)

\subsection{Corporate Image}

A review of research concerning corporate image shows that this concept has gained increasing interest since the 1950 s and the literature is moving toward a common and holistic definition. Boulding (1956) identified the corporate image as an organizational construct with "functional" and "emotional" meanings (cited in Kennedy, 1977). Martineau (1958) demonstrated that consumers who could relate with their retailers' projected image were more likely to purchase from those stores. Bernstein (1993) argued that corporate image should not be separated from the reality of the consumer's experience. Today, it is widely agreed that a strong and distinctive corporate image is key to sustainable competitive advantage (Davies et al., 2003; Melawar \& Karaosmanoglu, 2006).

An image can be described as a network of meanings, all of which are stored in the memory (Cornelissen, 2000). Corporate image is the perception that consumers hold in their mind about a company and its products and services; it is what comes to the audiences' minds when they see or hear about the organization (Gray \& Balmer, 1998). As such, the corporate image can be viewed as a multidimensional construct comprising a set of perceptions (Bolger, 1959; Bromley, 1993; Davies \& Chun, 2012; Holzhauer, 1999; Spector, 1961). However, corporate image is composed of elements beyond individual perception to encompass the sum of interactions from experiences, impressions, beliefs, feelings and knowledge between stakeholders and the organization (Balmer \& Gray, 2003; Worcester, 2009).

Corporate image is the impression created at a particular time and level of abstraction (Grunig, 1993); it is flexible and dynamic, and it changes depending on receivers' knowledge, attitude and behavior toward an organization at a given point (Williams \& Moffit, 1997). Corporations use marketing resources and internal operations to construct a desired mental picture for its audience, and that image is manifested in the associations created from customers' personal experiences and word-of-mouth as well as advertising and promotion (Dowling, 1993; Lemmink et al., 2003). Kennedy (1977) describes the corporate image as intangible emotional associations with psychological conditions that develop into feelings and attitudes, and he emphasizes the importance of employees as external communicators who can either enhance or degrade the corporate image. In addition, reliability and expertise can be a significant influence on the brand attitude reflecting toward brand image (Oh \& Park, 2020).

\section{Conceptual Framework and Hypotheses}

In the context of the above, pharmaceutical care can be described as a "philosophy of practice" that requires an array of competencies, including "attitudes, behaviors, commitments, concerns, ethics, functions, knowledge, responsibilities and skills with the goal of achieving definite therapeutic outcomes toward patient health and quality of life" (Boland et al., 2018). Hepler and 
Strand (1990) highlight pharmacy services as a social responsibility to reduce preventable pharmaceuticalrelated morbidity and mortality and emphasized the need for pharmacists to shift the focus of practice from products and biological systems to ensure the best drug therapy and safety for patients.

A pilot study entailing in-depth interviews with pharmacists revealed their belief that perceptions of quality that most impacted the corporate image of Thai PRS were perceived quality of responsiveness, i.e., a willingness to help customers and provide prompt service, as well as perceived empathy based on the caring and individualized attention the firm provides its customers. Therefore, this study focuses on responsiveness and empathy to measure the perceptions of service quality that consumers experienced during their PRS transactions compared to their expectation in the past 1 year. The aim was to measure how corporate image as the dependent variable was influenced by the independent variables of perceived service quality (manifested in empathy and responsiveness) and the cultural dimension (comprising the two main subconstructs of power distance and uncertainty avoidance) independent variables). Figure 1 depicts the resulting conceptual framework.

Based on the above, the following hypotheses were proposed to identify the relationship between corporate image and culture and corporate image and perceived service quality:

H1: There is no significant relationship between culture and the corporate image.

H2: There is no significant relationship between perceived service quality and the corporate image.

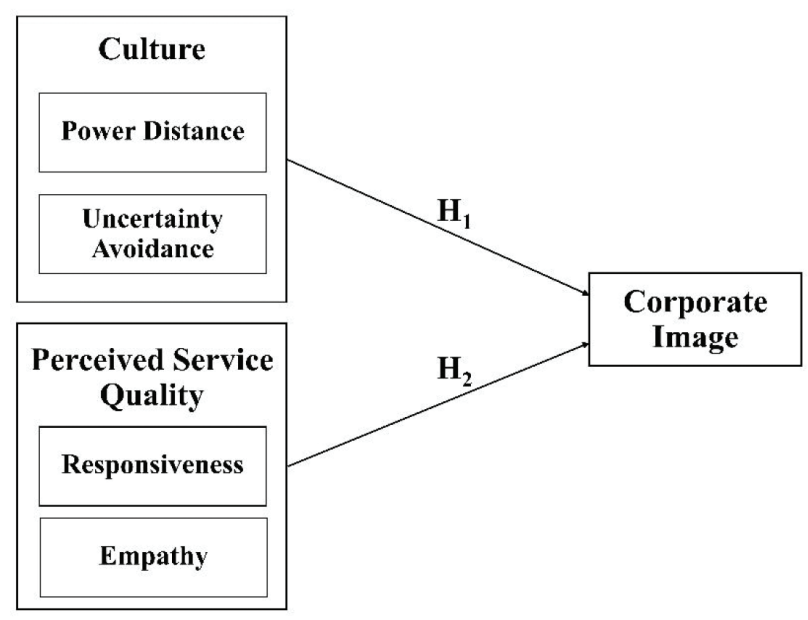

Figure 1: Conceptual Framework

\section{Research Methodology}

\subsection{Data Collection}

An exploratory mixed-method design characterized by qualitative and quantitative phases of data collection and analysis and the linking of data from these two separate data strands was adopted to conduct an in-depth interview with pharmacists and the owner of pharmacy retail stores as well as 405 respondents who had visited a pharmacy retail store and interacted with pharmacists during the previous year. A self-administrated and online questionnaire survey was administered to pharmacy patients as consumers. The formula to calculate the number of sample size was developed according to Cochran (1997). With a 95\% confidence level, the minimum number of respondents in this study is 385 , and data from 405 respondents were collected as the sample size. Essentially, increasing the number of samples will lead to more precise results because the larger sample size reduces sampling error and the width of the confidence interval (Zikmund, 2003).

The sampling technique used in this study is nonprobability sampling, which is widely considered suitable for the selection of respondents due to convenience, accessibility and proximity for the researcher. Zikmund (2003) explained that under the non-probability sampling method, the odds of any member being selected for a sample cannot be calculated. Malhotra et al. (2003) described this approach as an easy method for adapting convenience sampling to measure and assess phenomena with cooperative participants in a process that is cheaper and less time-consuming than other sampling techniques. Based on those advantages, the researcher is to choose the convenience sampling technique.

\subsection{Questionnaire Design}

The questionnaire itself was divided into two parts. The first part collected information on participants' gender, age, education, the period of visits and interactions with pharmacists at the PRS in the previous year. The second part was designed to measure the corporate image based on the perceived service quality and cultural dimensions. The SERVQUAL instrument was used to measure service quality according to the two dimensions of responsiveness and empathy. Within the cultural dimension, items related to power distance and uncertainty avoidance were measured on a four-point Likert scale with scores ranging from 1 (strongly disagree) to 4 (strongly agree). Table 1 presents the questionnaire items for each variable. The online survey method was considered suitable for collecting the respondents' data within the designated timeframe. 
Table 1: Scale Items included in the Questionnaire

\begin{tabular}{|c|c|c|c|}
\hline Variables & Items & Mean & S.D. \\
\hline \multirow{8}{*}{$\begin{array}{l}\text { Culture } \\
\text { (adapted from } \\
\text { Dameyasani \& Abraham, } \\
\text { 2013; Hofstede, et al., } \\
\text { 2010; Langat D. \& } \\
\text { Oduor P., 2015) }\end{array}$} & $\begin{array}{l}\text { Power Distance } \\
\text { 1. The pharmacist directly dispenses medicine and asks for } \\
\text { details of my symptoms. }\end{array}$ & 3.26 & 0.81 \\
\hline & $\begin{array}{l}\text { 2. The pharmacist asks my preference before dispensation. } \\
\text { (e.g., degree of concentration [in milligrams], local/ } \\
\text { international brand, price) }\end{array}$ & 3.04 & 0.89 \\
\hline & $\begin{array}{l}\text { 3. The pharmacist responds to my inquiries (e.g., asking for } \\
\text { more detail of my symptoms, explain medicine usage) while } \\
\text { dispensing medicine. }\end{array}$ & 3.20 & 0.82 \\
\hline & $\begin{array}{l}\text { Uncertainty Avoidance } \\
\text { 1. I prefer the pharmacist to spell out instructions for using } \\
\text { medicines before I decide to purchase and use them. }\end{array}$ & 3.47 & 0.61 \\
\hline & $\begin{array}{l}\text { 2. I remain loyal only to a brand or pharmacy that I am familiar } \\
\text { with and that assures me that I will recover my health. }\end{array}$ & 3.04 & 0.76 \\
\hline & $\begin{array}{l}\text { 3. I ensure that I can receive accurate information about } \\
\text { medicine from the pharmacy before deciding to purchase or } \\
\text { use it. }\end{array}$ & 3.28 & 0.65 \\
\hline & $\begin{array}{l}\text { 4. I read labels (e.g., ingredients, expiration date) and consult } \\
\text { with the pharmacist before deciding to purchase or use the } \\
\text { medicine. }\end{array}$ & 3.25 & 0.78 \\
\hline & $\begin{array}{l}\text { 5. Pharmacy rules and regulations (e.g., pharmacy license, } \\
\text { pharmacist license, the name of the pharmacy is on a sign in } \\
\text { front of the store) are important because they inform me what } \\
\text { the pharmacist does. }\end{array}$ & 3.43 & 0.64 \\
\hline \multirow{7}{*}{$\begin{array}{l}\text { Perceived Service Quality } \\
\text { (adapted from Furrer et al., } \\
\text { 2000; Jiang \& Wang, 2006) }\end{array}$} & $\begin{array}{l}\text { Responsiveness } \\
\text { 1. The pharmacist provides prompt service. }\end{array}$ & 3.24 & 0.66 \\
\hline & 2. The pharmacist is willing to help me. & 3.23 & 0.67 \\
\hline & $\begin{array}{l}\text { 3. The pharmacist is ready to respond to my requests or } \\
\text { concerns. }\end{array}$ & 3.28 & 0.65 \\
\hline & $\begin{array}{l}\text { Empathy } \\
\text { 1. The pharmacist pays attention to my inquiries. }\end{array}$ & 3.20 & 0.69 \\
\hline & 2. The pharmacist treats me with care. & 3.18 & 0.68 \\
\hline & 3. The pharmacist has my best interest at heart. & 3.19 & 0.64 \\
\hline & 4. The pharmacist understands my needs. & 3.22 & 0.60 \\
\hline \multirow[t]{5}{*}{$\begin{array}{l}\text { Corporate Image } \\
\text { (adapted from Huang } \\
\text { et al., 2014) }\end{array}$} & $\begin{array}{l}\text { Corporate Image } \\
\text { 1. I have a good impression of the pharmacy based on my } \\
\text { experience. }\end{array}$ & 3.05 & 0.66 \\
\hline & 2. The pharmacy is trustworthy and has good will & 3.11 & 0.63 \\
\hline & $\begin{array}{l}\text { 3. The pharmacy I visited has better reputation than the other } \\
\text { chain pharmacy stores. }\end{array}$ & 2.95 & 0.75 \\
\hline & 4. The pharmacy I visited has a good overall image. & 3.14 & 0.63 \\
\hline & $\begin{array}{l}\text { 5. The pharmacy is accredited with the Thai Food and Drugs } \\
\text { Association. }\end{array}$ & 3.26 & 0.64 \\
\hline
\end{tabular}




\subsection{Data Analysis}

Cronbach's alpha was calculated to assess the reliability and consistency of the instrument. In addition to numbers and percentages related to sociodemographic variables, Pearson's correlation coefficient was used to test two hypotheses, i.e., the relationships between culture, perceived service quality, and corporate image.

Multiple linear regression was applied to analyze corporate image as a dependent variable with culture as power distance and uncertainty avoidance and perceived service quality as responsiveness and empathy as independent variables/sub-variables.

\section{Results}

\subsection{Descriptive Analysis}

Table 2 summarizes the socio-demographic statistics of the 405 respondents. The majority of the respondents were female (53.58\%), 20-30 years old $(74.57 \%)$, and had a bachelor's degree $(76.30 \%)$. Over $71 \%$ had primarily visited and interacted with pharmacists at the PRS during the rainy or winter season.

Table 2: Profile of Respondents

\begin{tabular}{|l|c|c|}
\hline Variables & Frequency (f) & Percentage (\%) \\
\hline Gender & & \\
\hline Male & 188 & 46.42 \\
\hline Female & 217 & 53.58 \\
\hline Age & & \\
\hline $20-30$ years old & 302 & 74.57 \\
\hline $31-40$ years old & 61 & 15.06 \\
\hline $41-50$ years old & 21 & 5.19 \\
\hline 51-60 years old & 21 & 5.19 \\
\hline Education & & 76.30 \\
\hline $\begin{array}{l}\text { Bachelor's } \\
\text { degree }\end{array}$ & 309 & 22.96 \\
\hline Master's degree & 93 & 0.74 \\
\hline Doctoral degree & 3 & 28.40 \\
\hline $\begin{array}{l}\text { Period visited the } \\
\text { PRS }\end{array}$ & & 34.32 \\
\hline $\begin{array}{l}\text { Feb-May } \\
\text { (Summer) }\end{array}$ & 115 & 37.28 \\
\hline Jun-Oct (Rainy) & 139 & \\
\hline Nov-Jan (Winter) & 151 & \\
\hline
\end{tabular}

\subsection{Reliability}

Table 3 illustrates the results for reliability based on Cronbach's alpha obtained through total factors analysis. The questions are consistent and reliable if the alpha value is greater than 0.6 (Sekaran \& Bougie, 2016). The Cronbach's alpha coefficient test of all factors was analyzed during both pretest period with a small number of respondents $(\mathrm{N}=$ $30)$ as well as for the full sample of respondents $(\mathrm{N}=405)$. The results show that all factors are greater than 0.6. Thus, the researcher can conclude that all of the questions and associated factors are consistent and reliable.

\subsection{Inferential Analysis}

The results of the Pearson's correlation coefficient analysis are summarized in Table 4. The results indicate moderate correlations between both independent variables and corporate identity. The $\mathrm{p}$ values are significant in both cases, which means that the null hypotheses were rejected. Thus, it can be concluded that there is a significant moderate and positive relationship between culture and the corporate image as well as between perceived service quality and the corporate image $\left(\mathrm{H}_{1}\right.$ and $\mathrm{H}_{2}$ are supported). The level of correlation for the former is somewhat higher than that of the latter variable, approaching the "strong" threshold of 0.7 , thereby suggesting a closer relationship between corporate image and perceived service quality.

Table 3: Reliability Test with Cronbach's Alpha

\begin{tabular}{|l|c|c|c|}
\hline \multirow{2}{*}{ Variables } & \multirow{2}{*}{$\begin{array}{c}\text { No. of } \\
\text { items }\end{array}$} & \multicolumn{2}{|c|}{ Cronbach's Alpha } \\
\cline { 3 - 4 } & & $\mathbf{N}=\mathbf{3 0}$ & $\mathbf{N}=\mathbf{4 0 5}$ \\
\hline Culture & 3 & 0.78 & 0.77 \\
\hline Power Distance & 5 & 0.73 & 0.65 \\
\hline Uncertainty Avoidance & & & \\
\hline $\begin{array}{l}\text { Perceived Service } \\
\text { Quality }\end{array}$ & & & \\
\hline Responsiveness & 3 & 0.88 & 0.82 \\
\hline Empathy & 4 & 0.90 & 0.85 \\
\hline Corporate image & 5 & 0.89 & 0.84 \\
\hline
\end{tabular}

Table 4: The Relationship between the Independent Variables and Corporate Image

\begin{tabular}{|l|c|c|}
\hline Variables & $\boldsymbol{p}$-value & $\begin{array}{c}\text { Level of } \\
\text { correlation (r) }\end{array}$ \\
\hline Culture & $<.001$ & 0.571 \\
\hline Perceived service quality & $<.001$ & 0.695 \\
\hline
\end{tabular}




\subsection{Multiple Linear Regression (MLR) Analysis}

The multiple linear regression equation is divided into two equations using the main-independent variable (culture and perceived service quality) and sub-independent variables (power distance, uncertainty avoidance, responsiveness, and empathy) as follows:

\section{Main-independent variable}

Corporate Image $=0.548+0.197 \mathrm{X}_{1}+0.594 \mathrm{X}_{2}$

where $\mathrm{X}_{1}=$ Culture, and $\mathrm{X}_{2}=$ Perceived Service Quality

\section{Sub-independent variable}

Corporate Image $=0.531+0.064 \mathrm{Y}_{1}+0.142 \mathrm{Y}_{2}$

$$
+0.258 \mathrm{Y}_{3}+0.332 \mathrm{Y}_{4}
$$

where $\mathrm{Y}_{1}=$ Power Distance, $\mathrm{Y}_{2}=$ Uncertainty Avoidance, $\mathrm{Y}_{3}=$ Responsiveness, and $\mathrm{Y}_{4}=$ Empathy

All analyses were conducted using Statistical Analysis System (SAS) software version 7.1. The level of significance was set at $\mathrm{p}<.05$.

Table 5 presents the results of the multiple linear regression analysis. The results of equation (1) show the regression analysis of culture and perceived service quality as independent factors that affect the corporate image. The model was significant $(\mathrm{p}<0.001)$ with an $\mathrm{R}$-square value of 0.500 , thus indicating that $50 \%$ of the corporate image was interpreted by these factors. Culture $(p=0.003)$ is a significant variable with a positive effect on the corporate image and perceived service quality $(p<0.001)$ and also had a significant and positive relationship with the corporate image of Thai PRSs. Perceived service quality can explain the corporate image better than the culture at a magnitude of $50 \%$.

The results of equation (2) show the precise analysis using the sub-independent variables. The R-square value of 0.50 is the proportion of variance in the dependent variable that is indicated by the four sub-independent variables (power distance, uncertainty avoidance, responsiveness, and empathy) at a significance level of 0.002. Each sub-variable can be seen to have a significant positive influence on the corporate image. Each variable can be sequenced according to ascending importance as follows: 1) power distance $=0.064 ; 2$ ) uncertainty avoidance $=$ $0.142 ; 3$ ) responsiveness $=0.258$; and 4 ) empathy $=0.332$. Particularly, empathy explains $41.7 \%$ of the variance in corporate image.

\section{Discussion}

Two hypotheses were proposed in this study to analyze the relationship between the corporate image as a dependent variable and four factors as sub-independent variables of culture and perceived service quality. According to analyses of data collected from 405 respondents to consider the key factors influencing the corporate image of Thai PRS, the corporate image is significantly and positively affected by culture and its sub-variables of power distance and uncertainty avoidance as well as perceived service quality and its sub-variables of responsiveness and empathy. Thus, it can be concluded that hypotheses $\mathrm{H}_{1}$ and $\mathrm{H}_{2}$ are supported.

Table 5: Summary of Multiple Linear Regression Results for Corporate Image

\begin{tabular}{|l|c|c|c|c|}
\hline Variable & Parameter Estimate & Std. Error & $\mathbf{t}$ value & $\operatorname{Pr}>|\mathbf{t}|$ \\
\hline Intercept * & 0.548 & 0.136 & 4.04 & $<.001$ \\
\hline Culture & 0.197 & 0.054 & 3.63 & 0.003 \\
\hline Perceived Service Quality & 0.594 & 0.050 & 11.80 & $<.001$ \\
\hline Intercept (1) & 0.548 & 0.136 & 4.04 & $<.001$ \\
\hline Intercept (2) & 0.531 & 0.143 & 3.72 & 0.002 \\
\hline Culture & 0.197 & 0.054 & 3.63 & 0.003 \\
\hline Power Distance & 0.064 & 0.032 & 2.00 & 0.0466 \\
\hline Uncertainty Avoidance & 0.142 & 0.059 & 2.41 & 0.0165 \\
\hline Perceived Service Quality & 0.594 & 0.050 & 11.80 & $<.001$ \\
\hline Responsiveness & 0.258 & 0.044 & 5.80 & $<.001$ \\
\hline Empathy & 0.332 & 0.048 & 6.86 & $<.0001$ \\
\hline
\end{tabular}

${ }^{*} \mathrm{R}$-square $=0.50,{ }^{* *} \mathrm{R}$-square $(1)=0.50, \mathrm{R}$-square $(2)=0.50$ 


\subsection{Culture and Corporate Image}

The cultural elements of Power Distance (PD) and Uncertainty Avoidance (UA) are highly important to create the corporate image of Thai PRS. Schwartz and Davis (1981) describe a desirable culture as one characterized by organization-wide consensus and consistency (the integration perspective) to make the organization successful in the future. The study's results concerning PD imply that although pharmacists are perceived as having more knowledge and education than consumers, participants prefer their pharmacists maintain accessibility and equality while employing their expertise by directly dispensing medicine along with an inquiry for details of their symptoms. The findings also indicate that consumers try to avoid uncertain situations when they have to visit the pharmacy retail store. The end-consumers who participated in this study, before deciding to purchase and use medicines, prefer pharmacists to spell out instructions. As Zeithmal and Bitner (2000) emphasized, satisfied customers are more likely to continue to use a service and spread positive views that will help healthcare providers gain new patients without additional cost.

To be successful in creating the right corporate image and expanding Thai PRS in the ASEAN region, pharmacists should treat everyone equally and inquire about their endconsumers' symptoms during every visit before dispensing medicines, rather than determining symptoms from a professional viewpoint without asking the patient for details. While dispensing prescriptions, pharmacists should also clearly explain how to properly use the medicines.

\subsection{Perceived Service Quality and Corporate Image}

Perceived service quality based on responsiveness and empathy also plays a very important role in creating the corporate image of Thai PRS. Hong and Goo (2004) propose that high service quality will lead to higher satisfaction, which in turn will produce a greater willingness to recommend to the organization. The results of this study show that the participating end-consumers prefer pharmacists who are ready to respond to their requests or concerns and understanding patients' needs is the most important quality that they seek in their pharmacists.

To be successful in operating Thai PRS in ASEAN countries, pharmacists should be ready to respond to endconsumer requests or concerns, offer fast and efficient service, and provide sincere and detailed information. For example, if an end-consumer expresses concern, the pharmacist should respect his/her preference and dispense the medicine accordingly. Pharmacists need to understand each endconsumer's specific needs and look out for their best interests.
For example, some end-consumers may be reserved about providing details of their symptoms; however, responsive service means that pharmacists should express awareness of their medical conditions, answer their questions, recognize and pay attention to their emotional and social needs, and be available when needed (Zarei et al., 2012).

\section{Conclusions and Recommendations}

This study aimed to understand the factors influencing the corporate image of Thai Pharmacy Retail Stores (PRS) in order to recommend efforts to create the appropriate corporate image for use in expanding the business throughout the ASEAN region. Statistical analyses of data collected from 405 respondents who had visited PRS in the past year showed that there is a significant relationship between culture (power distance and uncertainty avoidance), perceived service quality (responsiveness and empathy), and corporate image. MLR resulted in R-square of 50\% which denotes the effect of the two independent variables on the image of Thai PRS. Perceived service quality was found to have a stronger impact than culture, and organizations can address this by placing primary emphasis on improving pharmacists' skills and capabilities.

This study recommends that Thai PRS should improve the following aspects. First, pharmacists should inquire about end-consumers' preferences before dispensation. (for example, degree of concentration [in milligrams], local vs. international brands, price). Second, pharmacists should service end-consumers with responsiveness and empathy to ensure that they remain loyal to the brands or pharmacies with which they are familiar and feel assured of recovering their health. Third, pharmacists should be willing to help end-consumers, and fourth, they should exhibit awareness when dealing with end-consumers.

\section{References}

Abu-Kharmeh, S. S. (2012). Evaluating the quality of health care services in the Hashemite Kingdom of Jordan. International Journal of Business and Management, 7(4), 195-205. https:// doi.org/10.5539/ijbm.v7n4p195

Afolabi, M. O., \& Erhun, W. O. (2003). Patients' response to waiting time in an out-patient pharmacy in Nigeria. Tropical Journal of Pharmaceutical Research, 2(2), 207-214. https:// doi.org/10.4314/tjpr.v2i2.14601

Baber, H. (2019). E-SERVQUAL and its impact on the performance of Islamic banks in Malaysia from the customer's perspective. The Journal of Asian Finance, Economics and Business, 6(1), 169-175. https://doi.org/10.13106/ jafeb.2019.vol6.no1.169

Balmer, J. M., \& Gray, E. R. (2003). Corporate brands: What are they? What of them? European Journal of Marketing, 37(7/8), 972-997. https://doi.org/10.1108/03090560310477627 
Bernstein, D. (1993). Company image \& reality: A critique of corporate communications. London, UK: Cassell Educational Ltd.

Boland, D., White, T., \& Adams, E. (2018). Experiences of pharmacy trainees from an interprofessional immersion training. Pharmacy, 6(37), 1-9. https://doi.org/10.3390/pharmacy6020037

Bolger, J. F. (1959). How to evaluate your company image. Journal of Marketing, 24(2), 7-10. https://doi. org/10.1177/002224295902400202

Boulding, K. E. (1956). The image. Ann Arbor, MI: University of Michigan Press.

Bromley, D. B. (1993). Reputation, image and impression management. New York, NY: John Wiley \& Sons.

Cochran, W. G. (1997). Sampling techniques. Hoboken, NJ: John Wiley \& Sons.

Cornelissen, J. (2000). Corporate image: an audience centred model. Corporate Communications: An International Journal, 5(2), 119-125. https://doi.org/10.1108/13563280010372540

Dameyasani, A. W., \& Abraham, J. (2013). Impulsive buying, cultural values dimensions, and symbolic meaning of money: A study on college students in Indonesia's capital city and its surrounding. International Journal of Research Studies in Psychology,2(4), 35-52. https://doi.org/10.5861/ijrsp.2013.374

Davies, G., \& Chun, R. (2012). Employee as symbol: Stereotypical age effects on corporate brand associations. European Journal of Marketing, 46(5), 663-683. https://doi. org/10.1108/03090561211212467

Davies, G., Chun, R., Da Silva, R. V., \& Roper, S. (2003). Corporate reputation and competitiveness. London, UK: Psychology Press.

Dowling, G. R. (1993). Developing your company image into a corporate asset. Long Range Planning, 26(2), 101-109. https:// doi.org/10.1016/0024-6301(93)90141-2

Furrer, O., Liu, B. S. C., \& Sudharshan, D. (2000). The relationships between culture and service quality perceptions: Basis for cross-cultural market segmentation and resource allocation. Journal of Service Research, 2(4), 355-371. https:// doi.org/10.1177/109467050024004

Gray, E. R., \& Balmer, J. M. (1998). Managing corporate image and corporate reputation. Long Range Planning, 31(5), 695-702. https://doi.org/10.1016/S0024-6301(98)00074-0

Grunig, J. E. (1993). Image and substance: From symbolic to behavioral relationships. Public Relations Review, 19(2), 121139. https://doi.org/10.1016/0363-8111(93)90003-U

Hepler, C. D., \& Strand, L. M. (1990). Opportunities and responsibilities in pharmaceutical care. American Journal of Hospital Pharmacy, 47(3), 533-543.

Hofstede Insights (2020). What about Thailand? Retrieved January 12, 2020, from https://www.hofstede-insights.com/country/ thailand/

Hofstede, G. (2001). Culture's consequences: Comparing values, behaviors, institutions and organizations across nations (2nd ed.). Thousand Oaks, CA: Sage Publications.
Hofstede, G. H. (1991). Cultures and organizations: Software of the mind. London, UK: McGraw-Hill.

Hofstede, G. H., Hofstede, G. J., \& Minkov, M. (2010). Cultures and organizations: Software of the mind (3rd ed.). New York, NY: McGraw-Hill.

Holland, R. W., \& Nimmo, C. M. (1999). Transitions, part 1: Beyond pharmaceutical care. American Journal of Healthsystem Pharmacy, 56(17), 1758-1764. https://doi.org/ 10.1093/ ajhp/56.17.1758.

Holzhauer, F. F. O. (1999). Corporate image and brand image: What brand merchandise advertising does for the corporate image. Handbook corporate communication, 2, 177-220.

Hong, S. C., \& Goo, Y. J. (2004). A causal model of customer loyalty in professional service firms: An empirical study. International Journal of Management, 21(4), 531-540.

Huang, C. C., Yen, S. W., Liu, C. Y., \& Huang, P. C. (2014). The relationship among corporate social responsibility, service quality, corporate image and purchase intention. International Journal of Organizational Innovation, 6(3), 68-84.

Jiang, Y., \& Wang, C. L. (2006). The impact of affect on service quality and satisfaction: The moderation of service contexts. Journal of Services Marketing, 20(4), 211-218. https://doi.org/10.1108/08876040610674562

Kennedy, S. H. (1977). Nurturing corporate images. European Journal of Marketing, 11(3), 119-164. https://doi.org/10.1108/ EUM0000000005007

Kingdom of the Netherlands (2018). Life sciences and health in Thailand. Retrieved January 15, 2020, from https://www. netherlandsworldwide.nl/binaries/en-nederlandwereldwijd/ documents/publications/2018/04/18/factsheet-life-sciences-health-in-thailand/Thailand+-+Factsheet+Life+Sciences $+\% 26$ + Health.pdf

Knoema (2020). Thailand - Current expenditure on health. Retrieved January 3, 2020, from https://knoema.com/atlas/ Thailand/topics/Health/Health-Expenditure/Expenditure-onhealth

Langat, D., \& Oudor, P. (2015). The effects of Hofstede's dimensions of culture on consumer purchase decisions amongst the Kipsigis community: A case study of Bomet county. Strategic Journal of Business and Change Management, 2(14), 249-267.

Lemmink, J., Schuijf, A., \& Streukens, S. (2003). The role of corporate image and company employment image in explaining application intentions. Journal of Economic Psychology, 24(1), 1-15. https://doi.org/10.1016/S0167-4870(02)00151-4

Malhotra, N. K., Birks, D. F., Palmer, A., \& Koenig-Lewis, N. (2003). Market research: An applied approach. Journal of Marketing Management, 27(1), 1208-1213. https://doi. org/10.1016/S0167-4870(02)00151-4

Martineau, P. (1958). Sharper focus for the corporate image. Harvard Business Review, 36(6), 49-58. 
Melawar, T. C., \& Karaosmanoglu, E. (2006). Seven dimensions of corporate identity: A categorisation from the practioners's perspective'. European Journal of Marketing, 40(7/8), 848-869. https://doi.org/10.1108/03090560610670025

Ngamsangchaikit, W. (2016). Thailand pushes health care tourism. Retrieved January 15, 2020, from https://www.ttrweekly.com/ site/2016/09/thailand-pushes-health-care-tourism/

Oh, A. H., \& Park, H. Y. (2020). The effect of airline's professional models on brand loyalty: Focusing on mediating effect of brand attitude. Journal of Asian Finance, Economics and Business, 7(5), 155-166. https://doi.org/10.13106/jafeb.2020.vol7. no5.155

Pakdil, F., \& Aydın, Ö. (2007). Expectations and perceptions in airline services: An analysis using weighted SERVQUAL scores. Journal of Air Transport Management, 13(4), 229-237. https://doi.org/10.1016/j.jairtraman.2007.04.001

Parasuraman, A., Berry, L. L., \& Zeithaml, V. A. (1991). Refinement and reassessment of the SERVQUAL scale. Journal of Retailing, 67(4), 420-450.

Parasuraman, A., Zeithaml, V. A., \& Berry, L. L. (1988). SERVQUAL: A multiple-item scale for measuring consumer perc. Journal of Retailing, 64(1), 12-40.

Schwartz, H., \& Davis, S. M. (1981). Matching corporate culture and business strategy. Organizational Dynamics, 10(1), 30-48. https://doi.org/10.1016/0090-2616(81)90010-3

Sekaran, U., \& Bougie, R. (2016). Research methods for business: A skill building approach (7th ed.). Chicester, UK: John Wiley \& Sons.

Spector, A. J. (1961). Basic dimensions of the corporate image. Journal of Marketing, 25(6), 47-51.

Tabash, M. I., Albugami, M. A., Salim, M., \& Akhtar, A. (2019). Service quality dimensions of e-retailing of Islamic banks and its impact on customer satisfaction: An empirical investigation of Kingdom of Saudi Arabia. Journal of Asian Finance, Economics and Business, 6(3), 225-234. https://doi. org/10.13106/jafeb.2019.vol6.no3.225
Thailand Board of Investment. (2018). Here's Thailand's plan to transform into Asia's next big medical hub. Retrieved January 10, 2020, from https://qz.com/1397519/heres-thailands-planto-transform-itself-into-asias-next-big-medical-hub/

Thailand Board of Investment. (2019). Towards becoming no. 1 medical hub of Asia. Retrieved January 12, 2020, from https:// www.boi.go.th/upload/content/BOI-brochure_medical_hub.pdf

Thailand Board of Investment. (2020). Thailand races ahead as global healthcare hub. Retrieved January 12, 2020, from https://www.boi.go.th/en/advertorial4

Tran, V. D. (2020). Assessing the effects of service quality, experience value, relationship quality on behavioral intentions. Journal of Asian Finance, Economics and Business, 7(3), 167-175. https://doi.org/10.13106/jafeb.2020.vol7.no3.167

Villako, P., \& Raal, A. (2007). A survey of Estonian consumer expectations from the pharmacy service and a comparison with the opinions of pharmacists. Pharmacy World \& Science, 29(5), 546-550. https://doi.org/10.1007/s11096-0079102-6

Wilson, A., Zeithaml, V., Bitner, M. J., \& Gremler, D. (2017). Services marketing: Integrating customer focus across the firm (7th ed.). New York, NY: McGraw-Hill.

Worcester, R. (2009). Reflections on corporate reputations. Management Decision, 47(4), 573-589. https://doi. org/10.1108/00251740910959422

World Travel and Tourism Council. (2019). Medical tourism: A prescription for a healthier economy. Retrieved January 20, from https://www.tourismknowledgecenter.com/publication/ medical-tourism-a-prescription-for-a-healthier-economy

Zarei, A., Arab, M., Froushani, A. R., Rashidian, A., \& Tabatabaei, S. M. G. (2012). Service quality of private hospitals: The Iranian Patients' perspective. BMC Health Services Research, 12(31), 1-7. https://doi.org/10.1186/1472-6963-12-31

Zikmund, W. G., Babin, B. J., Carr, J. C., \& Griffin, M. (2003). Business research methods (7th ed.). Mason, OH: Thomson South-Western. 